\title{
Value of Pollination Services in Farmlands Adjacent to Mau, Cherangany and Mt. Elgon Forests
}

\author{
Jonah Kiprop $^{1} \quad$ David Langat $^{2} \quad$ Joshua Cheboiwo $^{3} \quad$ Joram Kagombe $^{4} \quad$ Abdala Kisiwa $^{5}$ \\ Stella Gatama ${ }^{6} \quad$ Samson Okoth $^{7}$ \\ Kenya Forestry Research Institute - Muguga, P.O Box 20412 00200, Nairobi Kenya
}

\begin{abstract}
Pollination plays a vital role in crop yield and quality and by extension food security. Approximately $75 \%$ of global food crops depend on pollination services. Forests are the primary habitats of natural pollinators and communities farming near them benefit from this valuable supporting service. This study estimated the economic value of crop pollination dependency on natural forests within Mau, Cherangany and Mount Elgon Water Towers using the Pollination Value Array Tool developed by Food and Agricultural Organization (FAO). To determine the value of crop pollination on farmlands adjacent to the forests, a buffer zone of $5 \mathrm{~km}$ between the forest and the farms was developed using GIS. Using the developed maps, a list of pollination dependent crops grown within these zones was identified from the FAO tool. Crop production data were obtained from Ministry of Agriculture in all the Counties neighboring the three ecosystems. The crop data gathered include the quantity of crop harvested per season and the producer price in Ksh per metric ton. This data was entered into the Pollination value array tool which computes; the Total Economic Value of crop (TVC) and the Economic Value of Insect Pollinators (EVIP) using the Pollination Dependency Ratios (PDR) of the crops. The contributions of natural /insect pollinators to crop production in the Mau, Cherangany and Mt. Elgon were estimated at Ksh 314 million (12.7\%), 67 million $(9.7 \%)$ and 549 million $(17.4 \%)$ respectively. The total economic value attributed to insect pollination in the three ecosystems amounted to Ksh 931 million in 2015.
\end{abstract}

Keywords: Pollination Services, Crop Production, Pollination Dependence Ratio, Economic Value, Food security DOI: $10.7176 /$ JNSR/9-10-08

Publication date:May $31^{\text {st }} 2019$

\subsection{Introduction}

Agriculture is the backbone of Kenyan economy accounting for $24 \%$ of the Gross Domestic Product (GDP), it is dominated by smallholder farmers who are engaged in crop and livestock production (Salami et al., 2010). The performance of this sector directly affects economic development, food security and poverty alleviation. In recent years, the country has experienced severe food insecurity mainly caused by recurrent droughts. Food security is a priority for the Government with many programmes initiated to increase food production. However, over the years efforts have been directed to almost all production inputs except pollination (Mwangi et al., 2012). Pollination is among the building blocks of natural ecosystems which include others soil formation and nutrient cycling. Ecosystem services are benefits (goods and services) that humans derive from the ecosystems (Fisher et al., 2009). According to The Economics of Ecosystems and Biodiversity (TEEB) there are four categories of ecosystem services based on their functions namely provisioning, regulatory, cultural, spiritual and supporting. Pollination falls under the supporting service and for many years has not been recognized has an important input in the improvement of crop yields. Pollination is the transfer of pollen from anthers (male part of the flower) to the stigma (female part of the flower) in order for fertilization to take place (Lord and Russell, 2002). Pollination occurs for many flowering plants mainly facilitated by wind, water, gravity and animals. Bees are the most important insect pollinators others are flies, bats, wasps, beetles, birds, butterflies and moths (Maheshwari, 2003).

Pollination services are critically important to human health and wellbeing, due to a large number of crops $75 \%$ that depend on it to produce fruits or seeds (Ingram et al., 1996). Globally greater than $90 \%$ of vitamins A and $\mathrm{C}$ are derived from pollinator dependent crops (Chaplin et al., 2011), and over 35\% of total crop production depend on animal pollinators (Klein et al., 2007). Globally pollination services provided by managed bees and those freely provided by wild bees is valued at $\$ 216$ billion per year $9.5 \%$ of annual global crop value (Gallai et al., 2009).

Around the world, industrialized countries rely on honey bee (Apis mellifera) to provide pollination services to large monoculture farms of pollination dependent crops (Allsopp et al., 2008). This is in contrast to least developed countries such as Kenya where smallholder farmers rely on natural wild pollinators and domesticated bees to pollinate a variety of crops grown on farm. In analysing pollination support service pollination dependency is used as a measure of the level of impact that animal pollination has on the productivity of a particular plant. Pollination dependency is classified into 7 categories namely; essential, great, modest, little, shows an increase to breeding, doesn't show an increase to breeding and unknown based on the percentage reduction in yield of a particular crop if no pollination service is provided (FAO, 2012). Generally in terms of volume of production $60 \%$ of the global production is not dependent on pollinators, $35 \%$ depend on pollinators while the remaining $5 \%$ is 
unknown (Sandhu, 2016).

While the services provided by natural pollinators and bees are valuable only few studies measuring the value of pollination services have been undertaken. In United States the value of pollination service provided by wild and honey bees across all the landscapes is estimated at $\$ 3.07$ billion representing $13.3 \%$ of the total pollination service value (Losey and Mace, 2006). In UK the value of pollination is reported to be US\$ 321 million (Carreck and Williams, 1998) and in Australia US\$ 1.4 billion (Gordon and Davis, 2003). In developing countries very few studies have been done to assess the value of pollination services to crop production with most focusing on other factors of production (Free, 1999). Studies by Gikungu et al., 2006 in Kakamega forest found out that there is a high density of bee species ( 243 species), however due to intensification of agricultural activities a deforestation the services provided by the forest is threatened (Biota, 2004). Within the Kenya's major water towers; Mau, Cherangany and Mount Elgon Forest Ecosystems forest adjacent communities practice crop farming with the major pollination dependent crops being crops being tomatoes, beans, cowpeas, soybeans, coffee, pears and plums. The economic value provided by the natural pollinators within these forest ecosystems is very important and underpins the importance of conserving the pollination systems.

\subsection{MATERIALS AND METHODS}

\subsection{Study Site}

This study was undertaken in Mau, Cherangany and Mount Elgon forest ecosystems (Figure 1). The Mau Forest Complex forms the largest closed - canopy montane forest ecosystem in East Africa, covering approximately 400,000 hectares. It is situated at $0^{\circ} 30^{\prime}$ 'South, $35^{\circ} 20^{\prime}$ East within the Rift Valley region and spans seven counties: Baringo, Bomet, Elgeyo Marakwet, Kericho, Nakuru, Nandi, and Narok. The area is thus the largest Water Tower in the region, being the main catchment area for twelve rivers draining into Lake Baringo, Lake Nakuru, Lake Natron, Lake Turkana, and the trans boundary Lake Victoria (Kipkoech et al., 2011; Nabutola, 2010). The Makalia, Nderit, and Njoro rivers support Lake Nakuru ecosystems, including one of the largest bird sanctuaries in the world and an important tourism destination (Langat et al., 2016). The Cherangany forest ecosystem is located within an area defined at $1^{\circ} 16^{\prime}$ North $35^{\circ} 26^{\prime}$ East. It is comprised of forest reserves totaling $114,416.2$ hectares that transverse three counties: Elgeyo Marakwet, with the largest area of public forest at 74,250 hectares; West Pokot at 34,380 hectares; and Trans-Nzoia at 1,551.6 hectares. The Mt. Elgon ecosystem lies between $0^{\circ} 52^{\prime}$ and $01^{\circ} 25 \mathrm{~N}$, and between $34^{\circ} 14^{\prime}$ and $34^{\circ} 44 \mathrm{E}$. It is an extensive trans boundary resource between Kenya and Ugandacovering 2,223 square kilometers, of which 1,078 square kilometers fall on the Kenyan side. The ecosystem covers an area of about 772,300 hectares - made up of 221,401 hectares of protected areas and 550,899 hectares of farmlands and settlements - of which 180,000 hectares of the forest are in Kenya. The forest is an important regional resource that supports local economies through direct and indirect uses. In addition, the ecosystem provides biological, aesthetic, touristic, cultural, educational, employment, resource, and carbon sink values that are significant and could mitigate poverty and the likely negative effects of climate change. The three ecosystems form upper catchments for the major rivers, which originate as streams and gradually combine to form the rivers that drain into key water bodies. However, the Water Towers face immense challenges, including encroachment, conversion to agricultural land and human settlement, overgrazing, forest fires, and illegal harvesting and growing conflicts (KFS, 2015). 


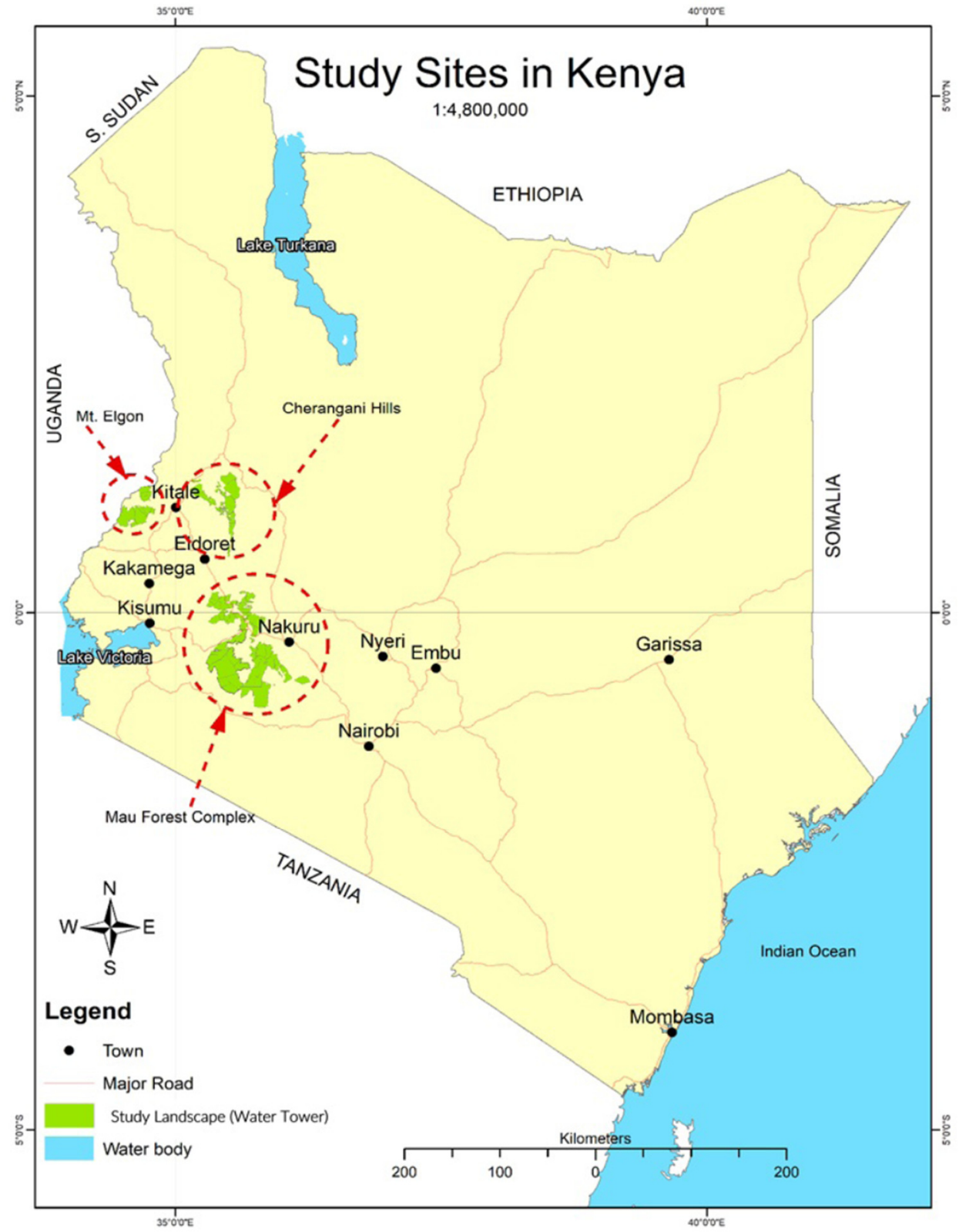

Figure 1: Mau complex, Cherangany Hills, and Mt. Elgon ecosystems in western Kenya

\subsection{Methodology}

The study used the most recent smallholder crop production data for the year 2015 obtained from the Ministry of Agriculture. The data was collected from Bomet, Kericho, Nandi, Uasin-Gishu, Kitale, Bungoma Kericho and Nakuru Counties. The crop data gathered focused on pollination dependent crops based on the FAO tool; key data collected for these crops include annual yield $(\mathrm{kg})$, total area of production (ha) and the annual average farm gate price. To determine the value of crop pollination on farmlands adjacent to the forests in the three ecosystems, a buffer zone of five kilometers between the forest and the farms was developed using geographic information systems (GIS). The crop data from these buffered zones were then entered into the pollination value array tool, which computes the total economic value of crops (TVC) and the economic value of insect pollinators (EVIP) using the pollination dependency ratios (PDR) of the various crops (FAO PIMS). The pollination dependency ratio on natural pollinators - the contribution of natural pollinators to crop yield in quantity and quality - is determined by comparing the yield from naturally pollinated flowers (unbagged flowers) with those denied pollination (bagged flowers; Kasina et al., 2007). Pollination Array Tool developed by FAO was used to determine the economic value of crop-pollination dependency.

This can be expressed as:

$p d r=\frac{Y_{u b}-Y_{b}}{Y_{u b}}+q c v$ 
Where $p d r$ is the pollination dependency ratio of a crop; $\mathrm{Y}_{\mathrm{ub}}$ is the yield (in kilograms) from unbagged flowers (with unlimited access by natural pollinators); $\mathrm{Y}_{\mathrm{b}}$ is the yield (in kilograms) from bagged flowers (not accessed by natural pollinators); $q v c$ is the quality coefficient value representing the value due to a better quality after natural pollination. $Q c v$ equals 0.1 if there is quality enhancement or 0.0 if otherwise $\frac{Y_{u b}-Y_{b}}{Y_{u b}}$ is the pollination dependency amount, $p d a$, which denotes the ratio of the amount of harvestable product (in kilograms) attributable to natural pollinators.

\subsection{RESULTS}

The total area dedicated to crops by farmers living adjacent to the Mau ecosystem in the 2015 was different for each crop. Data for eight crops namely beans, coffee, tomatoes, green grams, avocado, black beans, soybeans and cowpeas were obtained for the ecosystem. Beans had the highest area and economic value while cowpeas had the lowest (Table 2). The contribution of pollination to the income of the farmer depends on the impact it has on the crop yield. Where the impact is high, the change of income is also high. The benefits (in terms of income change) that accrued to the farmers in Mau ecosystem as a result of bee pollination of eight crops was about $12.7 \%$ (Ksh $314,628,225)$ of the annual market value of these crops in 2015. In Cherangany ecosystem data for nine crops were obtained namely tomatoes, beans, macadamia, pears, plums, coffee, passion fruit and tree tomatoes (Table 3). Beans had the highest yield and value followed by tomatoes while macadamia nuts had the lowest. The benefits that accrued to the farmers in Cherangany ecosystem as a result of bee pollination of the nine crops is about $9.7 \%$ $(67,142,543)$ of the annual value of these crops in 2015. Mount Elgon ecosystem had the highest number of pollination dependent crops. Data for a total of 17 crops was obtained (Table 4). Beans had the highest yield and value while Bambara Nuts had the lowest. The benefits that accrued to the farmers in Mount Elgon ecosystem as a result of bee pollination of the nine crops is about $17.4 \%(548,793,151)$ of the annual value of these crops in 2015

Table 2: Pollination (food production and landscape resilience) in Mau ecosystem

\begin{tabular}{|c|c|c|c|c|c|c|c|c|}
\hline \multirow[t]{2}{*}{ Crop } & \multirow[t]{2}{*}{ Crop Category } & \multirow[t]{2}{*}{$\begin{array}{l}\text { Pollination } \\
\text { Dependency } \\
\text { Ratio } \\
\text { Mean (D) }\end{array}$} & \multirow[t]{2}{*}{$\begin{array}{l}\text { Dependence } \\
\text { Upon } \\
\text { Animal } \\
\text { Pollination }\end{array}$} & \multirow[t]{2}{*}{\begin{tabular}{|ll|}
\multicolumn{2}{|l|}{ Producer } \\
Price & Per \\
Metric & Ton \\
(KES) & \\
\end{tabular}} & \multirow[t]{2}{*}{\begin{tabular}{|l|} 
Total \\
Economic \\
Value of Crop \\
(KES)
\end{tabular}} & \multirow{2}{*}{$\begin{array}{l}\text { Economic } \\
\text { Value of } \\
\text { Insect } \\
\text { Pollinators } \\
\text { (KES) }\end{array}$} & \multicolumn{2}{|c|}{$\begin{array}{l}\text { Consumer Surplus Loss } \\
\text { CSL With Elasticity } \\
\text { (KES) }\end{array}$} \\
\hline & & & & & & & -0.8 & \begin{tabular}{|l|}
-1.2 \\
\end{tabular} \\
\hline Beans (dry) & Pulse & 0.05 & Little & 48,487 & $1,429,542,221$ & $71,477,111$ & $73,703,332.28$ & $72,951,099.98$ \\
\hline Coffee & Stimulant Crops & 0.25 & Modest & 90,000 & $866,430,000$ & $216,607,500$ & $256,566,563$ & $242,221,287.9$ \\
\hline Tomatoes & Vegetables & 0.05 & Little & 22,500 & $88,425,000$ & $4,421,250$ & $4,558,953.951$ & $4,512,424.272$ \\
\hline Green Grams & Pulse & 0.05 & Little & 29,993 & $65,924,614$ & $3,296,231$ & $3,398,894.877$ & $3,364,205.013$ \\
\hline Avocados & Fruits & 0.65 & Great & 30,000 & $28,860,000$ & $18,759,000$ & $33,713,411.09$ & $27,328,532.11$ \\
\hline Black Beans & Pulse & 0.05 & Little & 55,000 & 550,000 & 27,500 & $28,356.51312$ & $28,067.10036$ \\
\hline Soybeans & Oil Crops & 0.25 & Modest & 22,222 & 133,332 & 33,333 & $39,482.16587$ & $37,274.61972$ \\
\hline Cowpeas & Vegetables & 0.05 & Little & 31,500 & 126,000 & 6,300 & $6,496.21937$ & $6,429.917537$ \\
\hline Total & & & & & $2,479,991,167$ & $314,628,225$ & & \\
\hline
\end{tabular}

Table 3: Pollination (food production and landscape resilience) in Cherangany ecosystem

\begin{tabular}{|c|c|c|c|c|c|c|c|c|}
\hline \multirow[t]{2}{*}{ Crop } & \multirow[t]{2}{*}{$\begin{array}{l}\text { Crop } \\
\text { Category }\end{array}$} & \multirow[t]{2}{*}{$\begin{array}{l}\text { Pollination } \\
\text { Dependency } \\
\text { Ratio Mean (D) }\end{array}$} & \multirow[t]{2}{*}{$\begin{array}{l}\text { Dependence } \\
\text { Upon } \\
\text { Animal } \\
\text { Pollination }\end{array}$} & \multirow[t]{2}{*}{\begin{tabular}{ll|}
\multicolumn{2}{|l|}{ Producer } \\
Price & Per \\
Metric & Ton \\
(KES) &
\end{tabular}} & \multirow[t]{2}{*}{\begin{tabular}{l|} 
Total \\
Economic \\
Value of Crop \\
(KES)
\end{tabular}} & \multirow[t]{2}{*}{$\begin{array}{l}\text { Economic Value } \\
\text { of Insect } \\
\text { Pollinators } \\
\text { (KES) }\end{array}$} & \multicolumn{2}{|c|}{$\begin{array}{l}\text { Consumer Surplus Loss } \\
\text { CSL With Elasticity } \\
\text { (KES) }\end{array}$} \\
\hline & & & & & & & -0.8 & -1.2 \\
\hline Beans (dry) & Pulse & 0.05 & Little & 51,763 & $483,880,524$ & $24,194,026$ & $24,947,572$ & $24,692,951$ \\
\hline Tomatoes & Vegetables & 0.05 & Little & 40,194 & $13,4247,960$ & $6,712,398$ & $6,921,462$ & $6,850,820$ \\
\hline Coffee & Stimulant Crops & 0.25 & Modest & 100,000 & $50,000,000$ & $12,500,000$ & 14805960 & $13,978,122$ \\
\hline Tree Tomatoes & Fruits & 0.95 & Essential & 83,333 & $12,499,950$ & $11,874,953$ & 51285058 & $28,169,870$ \\
\hline Passion Fruit & Fruits & 0.95 & Essential & 49,697 & $8,696,975$ & $8,262,126$ & 35682132 & $19,599,491$ \\
\hline Avocados & Fruits & 0.65 & Great & 22,500 & $3,510,000$ & $2,281,500$ & $4,100,280$ & $3,323,740$ \\
\hline Plums & Fruits & 0.65 & Great & 76,000 & $1,155,200$ & 750,880 & $1,349,471$ & $1,093,899$ \\
\hline Pears & Fruits & 0.65 & Great & 65,374 & 849,862 & 552,410 & 992,784 & 804,764 \\
\hline Macadamia Nuts & Tree Nuts & 0.95 & Essential & 25,000 & 15,000 & 14,250 & 61,542 & 33,804 \\
\hline Total & & & & & $694,855,471$ & $67,142,543$ & & \\
\hline
\end{tabular}


Table 4: Pollination (food production and landscape resilience) in Mt. Elgon ecosystem

\begin{tabular}{|c|c|c|c|c|c|c|c|c|}
\hline \multirow[t]{2}{*}{ Crop } & \multirow[t]{2}{*}{$\begin{array}{l}\text { Crop } \\
\text { Category }\end{array}$} & \multirow[t]{2}{*}{\begin{tabular}{|l|} 
Pollination \\
Dependency \\
Ratio Mean \\
(D)
\end{tabular}} & \multirow[t]{2}{*}{$\begin{array}{l}\text { Dependence } \\
\text { Upon } \\
\text { Animal } \\
\text { Pollination }\end{array}$} & \multirow[t]{2}{*}{\begin{tabular}{ll}
\multicolumn{2}{l}{ Producer } \\
Price Per \\
Metric & Ton \\
(KES) &
\end{tabular}} & \multirow[t]{2}{*}{\begin{tabular}{|l|} 
Total \\
Economic \\
Value of Crop \\
(KES)
\end{tabular}} & \multirow[t]{2}{*}{$\begin{array}{l}\text { Economic Value of } \\
\text { Insect Pollinators } \\
\text { (KES) }\end{array}$} & \multicolumn{2}{|c|}{$\begin{array}{l}\text { Consumer Surplus Loss } \\
\text { CSL With Elasticity } \\
\text { (KES) }\end{array}$} \\
\hline & & & & & & & -0.8 & -1.2 \\
\hline Beans (dry) & Pulse & 0.05 & Little & 44,444 & $1,312,431,320$ & $65,621,566$ & $67,665,411$ & $66,974,803$ \\
\hline Coffee & Stimulant & 0.25 & Modest & 86,000 & $1,213,460,000$ & $303,365,000$ & $359,328,811$ & $339,237,843$ \\
\hline Tomatoes & Vegetables & 0.05 & Little & 24463 & $211,433,709$ & $10,571,685$ & 10900950 & 10789693 \\
\hline Avocados & Fruits & 0.65 & Great & 28,811 & $107,551,463$ & $69,908,451$ & $125,638,485$ & $101,844,200$ \\
\hline Sunflower Seeds & Oil Crops & 0.25 & Modest & 30,000 & $76,530,000$ & $19,132,500$ & $22,662,003$ & $21,394,914$ \\
\hline Mangoes & Fruits & 0.65 & Great & 20,234 & $58,739,302$ & $38,180,546$ & $68,617,541$ & $55,622,276$ \\
\hline Green Grams & Pulse & 0.05 & Little & 66,666 & $33,719,663$ & $1,685,983$ & $1,738,494$ & $1,720,751$ \\
\hline Papaya & Fruits & 0.05 & Little & 46,433 & $33,060,296$ & $1,653,015$ & $1,704,499$ & $1,687,103$ \\
\hline Pumpkins & Vegetables & 0.95 & Essential & 38,468 & $27,119,940$ & $25,763,943$ & $111,268,260$ & $61,117,460$ \\
\hline Groundnuts & Oil Crops & 0.05 & Little & 86,363 & $25,217,996$ & $1,260,900$ & $1,300,172$ & $1,286,902$ \\
\hline Soybean & Oil Crops & 0.25 & Modest & 50,000 & $17,250,000$ & $4,312,500$ & $5,108,056$ & $4,822,452$ \\
\hline Cowpeas & Vegetables & \begin{tabular}{|l|}
0.05 \\
\end{tabular} & Little & 26,563 & $16,575,312$ & 828,766 & 854,578 & 845,856 \\
\hline Macadamia & Tree Nuts & 0.95 & Essential & 33,892 & $6,575,048$ & $62,46,296$ & $26,976,245$ & $14,817,519$ \\
\hline Watermelon & Vegetables & 0.95 & Essential & 33,892 & $6,575,048$ & $6,246,296$ & $26,976,245$ & $14,817,519$ \\
\hline Oranges & Fruits & 0.05 & Little & 40,000 & 4000,000 & 200,000 & 206,229 & 204,124 \\
\hline Lemons & Fruits & 0.05 & Little & 42,857 & 899,997 & 50,000 & 46,401 & 45,928 \\
\hline Bambara Nuts & Vegetables & 0.05 & Little & 80,000 & 240,000 & 12,000 & 12,374 & 12,248 \\
\hline Total & & & & & $3,151,379,094$ & $548,793,151$ & & \\
\hline
\end{tabular}

\subsection{Discussion}

Pollination plays a vital role in crop yield, quality, and, by extension, food security has exhibited by the results .The percentage contribution of pollination to total crops yield was an average of $13.3 \%$ which is quite substantial. Given that approximately 75 percent of global food crops depend on pollination services (Kasina and Kitui, 2007) this service cannot be underestimated. With forests ecosystems being the primary habitats of natural pollinators' communities farming near them benefit from this valuable supporting service. Farms adjacent to complex and bio diverse landscapes also experience lower pest pressure due to natural enemy populations supported by forest habitats (Bianchi et al., 2006). The contributions of natural and insect pollinators to crop production in farmlands adjacent to Mau, Cherangany, and Mt. Elgon is estimated at Ksh 930 million in 2015 (Tables 2, 3, and 4). Mount Elgon had the highest value of insect pollination at Ksh 549 million followed by Mau at Ksh 314 million and Cherangany Ksh 67 million and respectively. Generally the pollination in Kenya is a public good and is not managed in anyway unlike other countries, where it is managed and to some extent traded. Therefore the amounts calculated represent the value of feral pollination obtained by smallholder farmers living adjacent to these ecosystems. Although most farmers have little knowledge on the role of these pollinators, their farming activities can positively or negatively affect the presence of pollinators within the farms. This study compares well with other studies e.g Kasina et al., 2007 who determined the economic importance of pollination in crop production in Kakamega, Western Kenya, the difference is that this study was broader and focused on all pollinators. There is need to develop policies that encourage the conservation of natural pollinators given the empirical evidence of the magnitude of influence natural pollinators have on crop yields.

\subsection{CONCLUSIONS}

This study attempted to estimate the monetary value contributed by natural pollinators in farmlands adjacent to Mau, Cherangany and Mount Elgon forests. The results show that the highest net economic benefit of natural pollinators was gained from beans, coffee and tomatoes. In terms of the ecosystems Mount Elgon had the highest percentage contribution of pollination to total crops yield at $17.4 \%$ followed by Mau, $12.7 \%$ and Cherangany, $9.7 \%$. On average more than $13.3 \%$ of the net benefit gained by farmers for the selected crops was as a result of natural pollination. The measured economic value shows that pollination impacts of farmer's wellbeing. Therefore, efforts and policies should be put in place to manage pollination within the ecosystems through the promotion of good agricultural practices and conservation measures.

\subsection{ACKNOWLEDGEMENT}

We thank our partner agencies and organizations (KFS, KWS, WRMA, WSB, WSP, KWTA) and County Departments of Agriculture (Nakuru, Bomet, Kericho, Bungoma, Trans-Nzoia, Elgeyo Marakwet, West Pokot, and Uasin Gishu) for providing the data used in this assessment. We acknowledge the Center for International Forestry Research (CIFOR) in Nairobi for facilitating and coordinating activities related to this work. We also extend our sincere gratitude to the United States Agency for International Development (USAID) for funding this 
work and to the US Forest Service (USFS)-International Programs for the technical support to undertake this work. We highly acknowledge the technical guidance provided by professional peers and specialists in various fields, not named here, but whose expert opinions informed this study

\subsection{REFERENCES}

1. Allsopp, M, H. De Lange and R. Veldtman. (2008). Valuing insect pollination services with cost of replacement. PLoS One, 3(9), 3128.

2. Bianchi, F., Booij, C., and Tschantke, T. 2006. Sustainable pest regulation in agricultural landscapes: A review on landscape composition, biodiversity and natural pest control. Proc Biol Sci. 2006 Jul 22: 273(1595): 171527.

3. Biodiversity Monitoring Transect Analysis in Africa (BIOTA), 2004. Biodiversity in conversion: The influence of fragmentation and disturbance of East African highland rainforest. Final report of phase 1 (20012004)

4. Carreck, N., and Williams, I. (1998). The economic value of bees in the UK. Bee world, 79(3), 115-123.

5. Chaplin-Kramer, R., Tuxen-Bettman, K., and Kremen, C. (2011). Value of wildland habitat for supplying pollination services to Californian agriculture. Rangelands, 33(3), 33-41.

6. FAO, Pollination Information Management System (PIMS). Accessed at http://www.fao.org/pollination/pollination-database/en/.

7. Fisher, B., Turner, R. K., and Morling, P. (2009). Defining and classifying ecosystem services for decision making. Ecological economics, 68(3), 643-653.

8. Free, J. B. (1999). Pollination in the tropics. Bee keeping and development 50: 10-11

9. Gallai, N., Salles, J. M., Settele, J., and Vaissière, B. E. (2009). Economic valuation of the vulnerability of world agriculture confronted with pollinator decline. Ecological economics, 68(3), 810-821.

10. Gordon, J., and Davis, L. (2003). Valuing honeybee pollination. Rural Industries Research and Development Corporation, Canberra, 36

11. Ingram, M., Nabhan, G., and Buchmann, S. L. (1996). Our forgotten pollinators: Protecting the birds and bees. Global Pesticide Campaigner, 6(4), 1-12.

12. Kasina, M., Kraemer, M., Martius, C., and Wittmann, D. (2009). Diversity and activity density of bees visiting crop flowers in Kakamega, Western Kenya. Journal of Apicultural Research, 48(2), 134-139.

13. Kasina, M., Nderitu, J., Nyamasyo, G., and Oronje, M. L. (2007). Sunflower pollinators in Kenya: Does diversity influence seed yield?.

14. Kenya Forest Service (KFS). 2015. Cherangany Hills Forest Strategic Ecosystem Management Plan 20152040.

15. Kipkoech, A., Mogaka, H., Cheboiwo, J., and Kimaro, D. 2011. The total economic value of Maasai Mau, Transmara and East Mau forest blocks of the Mau forest, Kenya. Kisumu, Kenya: Lake Victoria Basin Commission Secretariat

16. Klein, A. M., Vaissiere, B. E., Cane, J. H., Steffan-Dewenter, I., Cunningham, S. A., Kremen, C., and Tscharntke, T. (2007). Importance of pollinators in changing landscapes for world crops. Proceedings of the Royal Society of London B: Biological Sciences, 274(1608), 303-313.

17. Langat, D.K., Maranga, E.K., Aboud, A.A., and Cheboiwo, J.K. 2016. Role of forest resources to local livelihoods: The case of East Mau forest ecosystem, Kenya. International Journal of Forestry Research.

18. Lord, E. M., and Russell, S. D. (2002). The mechanisms of pollination and fertilization in plants. Annual review of cell and developmental biology, 18(1), 81-105.

19. Losey, J. E., and M. Vaughan. 2006. The economic value of ecological services provided by insects. BioScience 56:311-323

20. Maheshwari, J. K. (2003). International Society of Environmental Botanists. Environmental news Newsletter of ISEB India 9(1):3. http//isebindia.com/01_04.

21. Mwangi, D., Kasina, M., Nderitu, J., Hagen, M., Gikungu, M., and Kraemer, M. (2012). Diversity and abundance of native bees foraging on hedgerow plants in the Kakamega farmlands, western Kenya. Journal of Apicultural Research, 51(4), 298-305.

22. Nabutola, W. 2010. The Mau Forest: Kenya's largest water tower - a perfect model for a sustainable development project. Unpublished paper presented at the FIG Congress, Sydney, Australia.

23. Salami, A., Kamara, A. B., and Brixiova, Z. (2010). Smallholder agriculture in East Africa: Trends, constraints and opportunities. Tunis: African Development Bank.

24. Sandhu, H., Waterhouse, B., Boyer, S., and Wratten, S. (2016). Scarcity of ecosystem services: an experimental manipulation of declining pollination rates and its economic consequences for agriculture. Peer J, 4, e2099. 